\title{
The Effects of Human Resources Management on Developing Teachers of Non-Public Universities in Vietnam
}

Tran Viet Anh

Saigon Contruction corporation, Vietnam

E-mail: travian@gmail.com

Received: October 27, 2020 Accepted: December 7, 2020 Published: December 11, 2020

doi:10.5296/bms.v11i2.18057ＵRL: https://doi.org/10.5296/bms. v11i2.18057

\begin{abstract}
Human resources management in Private Universities have a big impact on the development of human resources for lecturers in universities. Human resources management mainly affect the development of resourse of lecures in a university, which can be divided into the 8 functions: Recruitment, arrangement and utilization of lecturers, working environment, human resource development policy, remuneration and compensation policy, training and development, school information communication, and school budget. Among these 8 factors, recruitment has the biggest influence and human resource development policy has the smallest influence on the development of the university's faculty. Based on the research results, the author has given some recommendations about managing human to promote the development of faculty in private universities.
\end{abstract}

Keywords: Human Resources Management, development of faculty in non-public universities

\section{Situation}

Over nearly 30 years of building and development, non-public education in Vietnam has had a remarkable development. Initially, there were only 5 non-public universities, so far there are 60 non-public universities, accounting for $25 \%$ of the total number of nationwide universities and institutes (now there are 235 universities, institutes and academies nationwide). The number of students and lecturers was very small, by the 2018-2019, the non-public education system had 15,158 lecturers (accounting for $20.8 \%$ of the total number of teachers nationwide) and 243,975 students enrolled (accounting for $13.80 \%$ of the total number of students 
nationwide), contributing to the state budget reached 111 billion dong. If the Government has to spend around 25 million VND per student per year in public universities. However, for the 2018-2019, non-public universities have saved about 6,000 billion VND. The above results show thatthe non-public education system plays a good role in contributing to the training of high quality human resources for the society. In addition to the achievements, the non-public education system still has many problems.

Firstly, lecturers who are belonged to the university are very few, and the qualifications of teachers are limited. Most of the teachers who are highly qualified and have a degree are elderly. They just can teach at non-public universities after retiring from public universities.

Secondly, it is very difficult to attract young and highly qualified teachers with degrees to be lecturers.

Thirdly, the lecturers at non-public universities are not stable. Many young teachers after a period of striving for higher degrees, they apply to transfer to public universities or quit to work there, so in fact, the faculty at non-public universities is only $20 \%$ of the requirements.

How to change the way to manage human resources at non-public universities, which helps to support the development of faculty to adapt for current requirements. That is a question for human resource management.

The article focuses on analyzing in-depth the impact of human resource management on the development of faculty at non-public universities in Vietnam.

\section{Literature Review}

\subsection{Human Resource Management Affects the Development of Lecturers}

Human resources management is affecting the development of lecturers at non-public universities include the following main factors:

\section{- Policy for developing human resources of lecturers (CSPTNNL)}

The human resources development policy of a university is a system of perspectives and goals on training, using and developing human resources with specific actions which are affirmed and applied to solve problems by the school's leadership in the process of developing lecturers.

The human resources development policy of a university will fundamentally determine the development of faculty at this university (Mikkelsen, A. and Grønhaug, K., 1999),. According to Pellert, A. (2007) and Spottl, G. (2013), HR development policy for faculty in universities includes the selection of development goals, action methods to achieve the goals and supporting policy for developing faculty at universities.

Many studies have shown that in order to develop faculty, firstly, universities need to have a correct and accurate policy on developing human resources (Verloop, N., Driel, JV, \& Meijer, P, 2001; Wiske, S., 2001; Mikkelsen, A. and Grønhaug, K., 1999; Verloop, N., Driel, JV, \& 
Meijer, P, 2001). King Abdulaziz and Jamia Millia Islamia (2014) Researches such as Verloop, N., Driel, JV, \& Meijer, P (2001) go into depth analysis of the role of goal setting and human resource development strategy in influencing the building faculty of the university.

\section{- Remuneration and compensation policy for lecturers (CSDN\&TL)}

Compensation is an individual reward which is received to exchange for his or her labor. Remuneration includes something about financial and non-financial (Griffin, GA (Ed.) (1983). Remuneration and compensation policies commensurate with the dedication of faculty which will have a positive effect on the development of faculty staff at the university. The reseach of Griffin, GA (Ed.) (1983) analyzes the role of remuneration and compensation policies for faculty to attract potential teachers from outside. It is also the motivation for talent people to develop their careers path. Potiyanuwat, P \& Wiratchai, N (1999) emphasized the role of material and financial incentives for workers. According to Pitiyanuwat, P et al., although making money is not the only motivation for them to develop their talents but it has an important role for them to devote to their full potential because in the end people go to work because of the money. Supporting the idea that universities should increase remuneration and compensation for faculty and see it as an important tool to encourage potential and talented faculty, there are also some researchs such as (Norton, L., J. Richardson, J. Hartley, S. Newstead, and J. Mayes, 2005; Verloop, N., Driel, J.V., \& Meijer, P, 2001; etc).

\section{- The recruitment (TD)}

Recruitment is the process of collecting human who are suitable to the needs of an organization to meet the requirements of performing jobs in that organization. Recruitment is a part of the development of human resources in terms of quantity for the organization and has a significant impact on the quality of the recruited human resources Weick, K. E. (1976) and Werner, J.M .; DeSimone, R.L. (2012). Recruitment has an impact on the development of lecturers of faculty in terms of quantity (increasing human resources from outside to the university) and at the same time affecting the quality of the recruited faculty (Khan , I .A, 2012; Griffin, G.A. (Ed.), 1983; Pawar, I.A. \& Mouli, S.C, 2008) .The studies of Ellis et al. (2012); Hales and Clarke (2016); Weick, K. E. (1976) and Werner, J.M ; DeSimone, R.L (2012) said that recruiting new faculty for the university is related to the university's human resources development strategy in terms of both quantity and quality. Authors such as Khan, I .A (2012); Griffin, GA (Ed.), (1983); Pawar, IA \& Mouli, SC (2008) analyzed how to recruit to ensure attracting talents for the university while ensuring resonable cost for recruitment. Recruitment must be in line with the university's development strategy in general and the human resources development strategy in particular.

\section{- Training and development of faculty of a university (ĐT\&PT)}

The training and development of university faculty is one of the most important factors affecting the development of faculty human resources of universities (Spottl, G. (2013). According to research by Nguyen Van Ha (2008) the quality of human resources is the most important measure of the human resources development of an organization and in which 
training and development plays a key role for creating the quality of human resources of that organization.

Many researches have affirmed the important role of training and development has a significant impact on the development of human resources of university faculty. Some recent prominent studies are Spottl, G. (2013); Pellert, A. (2007); Vincent-Lancrin, S. (2011); Vincent-Lancrin, S. (2011); Goswami, D. (2010); both affirm the role of training and development in relation to faculty development, but the studies all emphasize: training and developing need to clearly define who to be trained, who are trained with prospects or not? Training methods and forms of training, etc. should be flexible, not too rigid.

\section{- School budget (NS)}

The budget of a university is understood as all the school's revenues and expenditures made in one year to ensure that the school can operate and perform its educational and training functions. Roger Bennetta and Suzanne Kaneb (2014) and IntakhabAlam Khan and A.Naseeb Khan (2014) also emphasized the importance of school budget related to the development of human resources of the university's faculty. The authors focus on analyzing the effects of finance that affect all activities of the university, including the university's human resources development. The above authors all said that besides there are many tools to develop human resources of faculty, the factor of school budget is important that cannot be skipped. Managers need solutions to increase income for the school through teaching activities, researching applied topics for production and business units, or expand social relations to attract funding from individuals as well as government and non-government organizations.

Synthesizing researches, the author has synthesized activities affecting the development of human resources of university faculty as following table.

Table 1. Managing activities have effects on development of HR faculty in a university

\begin{tabular}{|l|l|l|}
\hline No. & Activities & Authors of researches \\
\hline 1 & $\begin{array}{l}\text { School information } \\
\text { communication }\end{array}$ & $\begin{array}{l}\text { Goswami, D. (2010), Griffin,G.A.(Ed.) (1983) và Khan, } \\
\text { I A. (2012). Pawar,I.A.\&Mouli,S.C.(2008)); } \\
\text { (Griffin,G.A.(Ed.) (1983); }\end{array}$ \\
\hline 2 & $\begin{array}{l}\text { Arrangement and } \\
\text { utilization of lecturers }\end{array}$ & $\begin{array}{l}\text { của K Akyeampong, K Lussier, J Pryor \& J Westbrook, } \\
\text { 2013; M Akiba, YL Chiu, K Shimizu \& G Liang, 2012; (K } \\
\text { Akyeampong, K Lussier, J Pryor \& J Westbrook, 2013). }\end{array}$ \\
\hline 3 & $\begin{array}{l}\text { Work-place at the } \\
\text { Mniversity }\end{array}$ & $\begin{array}{l}\text { Akyeampong, J Pryor, J Westbrook \& K Lussier, (2013); } \\
\text { Kwakman, K. (2003), M Akiba, YL Chiu, K Shimizu \& G } \\
\text { Liang (2012); Mikkelsen, A. and Grønhaug, K. (1999), } \\
\text { Kwakman, K. (2003), }\end{array}$ \\
\hline
\end{tabular}




\begin{tabular}{|l|l|l|}
\hline 4 & $\begin{array}{l}\text { Human } \\
\text { development policy }\end{array}$ & $\begin{array}{l}\text { Verloop, N.,Driel, J.V.,\& Meijer, P.(2001), Wiske,S. } \\
\text { (2001); Mikkelsen, A. and Grønhaug, K. (1999), Verloop, } \\
\text { N.,Driel, J.V.,\& Meijer, P. (2001); King Abdulaziz và } \\
\text { Jamia Millia Islamia (2014); Verloop, N.,Driel, J.V.,\& } \\
\text { Meijer, P.(2001) }\end{array}$ \\
\hline 5 & $\begin{array}{l}\text { Remuneration } \\
\text { compensation policy }\end{array}$ & $\begin{array}{l}\text { (Griffin,G.A.(Ed.) (1983); Pitiyanuwat, P \&Wiratchai, N } \\
\text { (1999); Norton, L., J. Richardson, J. Hartley, S. Newstead, } \\
\text { and J. Mayes (2005); Verloop, N.,Driel, J.V.,\& Meijer, P } \\
(2001)\end{array}$ \\
\hline 6 & Recruitment & $\begin{array}{l}\text { Ellis et al . (2012); Hales và Clarke, (2016); Weick, K. E. } \\
\text { (1976); Werner, J.M.; DeSimone, R.L. (2012); Khan, I .A. } \\
(2012) ; \text { Griffin,G.A.(Ed.) (1983); Pawar,I.A.\&Mouli,S.C. } \\
(2008)\end{array}$ \\
\hline 7 & $\begin{array}{l}\text { Training } \\
\text { development }\end{array}$ & and \\
\hline 8 & $\begin{array}{l}\text { Spottl, G. (2013); Pellert, A. (2007); Vincent-Lancrin, S. } \\
(2011) ; \text { Vincent-Lancrin, S. (2011); Goswami, D. (2010); }\end{array}$ \\
\hline
\end{tabular}

Sources: Synthesis of author

\subsection{Developing Human Resources of Lecturers in Universities}

The development of lecturer human resources in a university is the process of developing among quantity, quality and structure of lecturers of a university which is more and more reasonable to meet the development requirements of the university. It is the process of increasing the quantity, improving the quality on the physical, mental, skill and spiritual aspects along with the change in the human resource structure that is increasingly reasonable to meet the teaching requirements of the university.

Quantitative development: showing the increase in quantity, but ensuring the structural synchronization in the faculty, including: age structure, gender structure, industrial job structure. Industrial job structure means the ratio of lecturers among divisions, faculties and programs of disciplines. If this ratio is consistent with the prescribed norm, there will be a reasonable professional structure.

Quality development: The quality of university faculty shows development in the following 3 basic factors:

- Professional capacity: is the professional level where the lecturer is trained at the bachelor, master or doctor level. 
- Research capacity: lecturers' scientific research capacity is shown in published scientific works, especially those published in international journals; these researches will enhance the credibility of individuals and organizations, which have an important supportive effect on improving the quality of lecturers and instruction for students about scientific researches.

- Pedagogical capacity is a psychological capacity, expressing the proficiency and artistic and creative level of teachers in teaching activities, it includes a system of skills: communication skills; pedagogical behavior; writing boards and presenting boards; using teaching technical methods; organize and control students' independent work; convey information to students in a concise, easy to understand way; proficient use of language and non-verbal language; educating and convincing to form beliefs for learners.

\section{Research Methods}

\subsection{The Researches Are Carried Out as Following Steps}

Step 1: synthesize documents on managing activities affecting the development of human resources of faculty of the university as a base for building research model.

Step 2: From the synthesis of research results, the research model of managing activities affecting the development of faculty of non-public university was initially established.

The results of the synthesis of research documents and initial interview results have identified 80 criteria showing the related factors affecting the development of faculty of non-public university. In order to reduce the number of these observed variables to make the research model simpler and more focused on the research problem, a group of 5 experts was invited to evaluate.

Using the Delphi round 2 questionaire method to evaluate:

Round 1: each expert will evaluate the representativeness of the criteria representing each factor, the criteria that are duplicated or reflect the impact of factors with faintness will be removed.

Round 2: experts discuss to give the final assessment of the criteria for which criteria have not been reached. Finally, the criteria are selected which will be added as a scale of the impact assessment model of the factors on the development of faculty of non-public university.

Step 3: Based on the evaluation criteria of the scale of the impact of managing activities on the development of faculty of non-public university will be tested through survey evaluation of the subjects as it is mentioned above. The assessment scale of the survey uses a Likert scale of 5 levels: 1: strongly disagree; 2: disagree a part; 3: neutral; 4: agree; 5: strongly agree. 
Step 4: Set up the questionnaire, determine the sample size.

Step 5: Conduct collecting data. Collected data will be encrypted and scanned, then put into SPSS software. Run and process data. Conduct tests, run the results and then analyze the results.

\subsection{Research Design}

\subsubsection{Research Sample Identification}

- Sample size:

The number of survey samples is calculated according to a random formula to ensure the representative of the study. The sample is determined by the formula Slovin as follows:

$$
\mathrm{n}=\mathrm{N} /\left(1+\mathrm{N} * \mathrm{a}^{2}\right)
$$

Where n: sample size; N: Overall sample - According to the Ministry of Education and Training's statistics by 2018 the number of non-public university lecturers is $\mathrm{N}=15158$

å: sample confidence level $=0.05 ;$ Result $\mathrm{n}=390$

\section{- Subject:}

The sample includes lecturers from non-public universities, managing level: principals, administrators and faculty in departments of the university. Senior lecturers were divided into 4 levels: less than 5 years; 5 - 10 years; 10 - 15 years and over 15 years. With enough qualifications from bachelor to doctorate.

Table 2. Descriptive statistic of research samples

\begin{tabular}{|l|l|l|l|}
\hline Objects & Ratio & $\begin{array}{l}\text { Percentage } \\
(\boldsymbol{\%})\end{array}$ & $\begin{array}{l}\text { Accumulated } \\
\text { percentage (\%) }\end{array}$ \\
\hline$(1)$ & $(2)$ & $(3)$ & $(4)$ \\
\hline 1. Gender & & & \\
\hline Male & 178 & 45.6 & 45.6 \\
\hline Female & 212 & 54.4 & 100.0 \\
\hline Total & $\mathbf{3 9 0}$ & $\mathbf{1 0 0 . 0}$ & \\
\hline 2. Age & & & \\
\hline Under 30 years old & 14 & 3.7 & 3.7 \\
\hline 30- under 40 years old & 129 & 33.0 & 36.7 \\
\hline 40- under 50 years old & 137 & 35.2 & 71.9 \\
\hline From 50 years old & 110 & 28.1 & 100.0 \\
\hline Total & $\mathbf{3 9 0}$ & $\mathbf{1 0 0 . 0}$ & \\
\hline 3. Qualification & & & \\
\hline Bachelor Degree & 70 & 17.8 & 17.8 \\
\hline Master Degree & 66 & 17.0 & 34.8 \\
\hline
\end{tabular}




\begin{tabular}{|l|l|l|l|}
\hline Objects & Ratio & $\begin{array}{l}\text { Percentage } \\
(\mathbf{\%})\end{array}$ & $\begin{array}{l}\text { Accumulated } \\
\text { percentage (\%) }\end{array}$ \\
\hline Doctorate & 254 & 65.2 & 100.0 \\
\hline Total & $\mathbf{3 9 0}$ & $\mathbf{1 0 0 . 0}$ & \\
\hline 4. Position & & & \\
\hline Administrators & 101 & 25.9 & 25.9 \\
\hline Head and vice-head of Field & 100 & 25.6 & 51.5 \\
\hline Head and vice-head of Subject & 118 & 30.4 & 81.9 \\
\hline Lecture & 71 & 18.1 & 100.0 \\
\hline Total & $\mathbf{3 9 0}$ & $\mathbf{1 0 0 . 0}$ & \\
\hline 5. Experience & & & \\
\hline Under 5 years & 10 & 2.6 & 2.6 \\
\hline 5 - under 10 years & 111 & 28.5 & 31.1 \\
\hline 10 - 15 years & 120 & 30.7 & 61.9 \\
\hline Over 15 years & 148 & 38.1 & 100.0 \\
\hline Total & $\mathbf{3 9 0}$ & $\mathbf{1 0 0 . 0}$ & \\
\hline
\end{tabular}

Source: Author's synthesis

- Design a questionnaire for the survey:

The questionnaire is designed with 3 parts:

- Part 1: introduce to the respondents about the purpose and meaning of the survey and guarantee the confidentiality of the information they provide.

- Part 2: Find out the respondent's personal information.

- Part 3: Find out the extent of the respondents' assessment of statements related to external environmental factors and internal environmental factors and the development of faculty of the university.

The questions (observation) of influencing factors are built to reflect the nature of those factors. To ensure this requirement, the questions are built on the theoretical basis of factors affecting the development of faculty of non-public university together with the consultation of experts.

Survey results, after being collected, will be scanned, encoded, data entered and processed by using SPSS software.

\section{Research Results}

\subsection{Performing Exploratory Factor Analysis (EFA) of Human Resource Management}

Test results KMO and Barlett's Test showed KMO $=0.875>0.5$ and Sig Barlett's Test $=0.00$ $<0.05$. Thus, the sample size is suitable enough to conduct analizing factors. The EFA results show that there are 8 factors extracted from 34 observed variables measuring the properties in 
a group of managing activities and the observed variables with load coefficients bigger than 0.5 will be accepted. . These 8 extracted factors $61,706 \%$ variance and named include: School information communication (TT); Arrangement and utilization of lecturers (BTSD); Working environment (MTLV); Remuneration and compensation policy (CSDN\&TL); human resource development policy (CSD); Recruitment (TD); Training and development (DT\&PT); School budget (NS). The results of the discovery factor analysis EFA are shown in the table below.

Table 3. The discovery factor analysis EFA

\begin{tabular}{|c|c|c|c|c|c|c|c|c|}
\hline \multirow{2}{*}{$\begin{array}{l}\text { The observed } \\
\text { variables }\end{array}$} & \multicolumn{8}{|c|}{ Factors } \\
\hline & 1 & 2 & 3 & 4 & 5 & 6 & 7 & 8 \\
\hline TT1 & 0,715 & & & & & & & \\
\hline TT2 & 0,714 & & & & & & & \\
\hline TT3 & 0,817 & & & & & & & \\
\hline TT4 & 0,745 & & & & & & & \\
\hline BTSD1 & & 0,753 & & & & & & \\
\hline BTSD2 & & 0,687 & & & & & & \\
\hline BTSD3 & & 0,817 & & & & & & \\
\hline BTSD4 & & 0,634 & & & & & & \\
\hline MTLV1 & & & 0,794 & & & & & \\
\hline MTLV2 & & & 0,803 & & & & & \\
\hline MTLV3 & & & 0,76 & & & & & \\
\hline MTLV4 & & & 0,808 & & & & & \\
\hline MTLV5 & & & 0,806 & & & & & \\
\hline CSDN\&TL1 & & & & 0,783 & & & & \\
\hline CSDN\&TL2 & & & & 0,765 & & & & \\
\hline CSDN\&TL3 & & & & 0,854 & & & & \\
\hline CSPTNNL1 & & & & & 0,672 & & & \\
\hline CSPTNNL2 & & & & & 0,763 & & & \\
\hline CSPTNNL3 & & & & . & 0,872 & & & \\
\hline CSPTNNL4 & & & & & 0,765 & & & \\
\hline CSPTNNL5 & & & & & 0,787 & & & \\
\hline TD1 & & & & & & 0,766 & & \\
\hline TD2 & & & & & & 0,754 & & \\
\hline TD3 & & & & & & 0,678 & & \\
\hline TD4 & & & & & & 0,772 & & \\
\hline DT\&PT1 & & & & & & & 0,782 & \\
\hline DT\&PT2 & & & & & & & 0,873 & \\
\hline DT\&PT3 & & & & & & & 0,768 & \\
\hline DT\&PT4 & & & & & & & 0,77 & \\
\hline
\end{tabular}




\begin{tabular}{|l|l|l|l|l|l|l|l|l|}
\hline DT\&PT5 & & & & & & & 0,754 & \\
\hline NS1 & & & & & & & & 0,76 \\
\hline NS2 & & & & & & & & 0,82 \\
\hline NS3 & & & & & & & & 0,65 \\
\hline NS4 & & & & & & & & 0,72 \\
\hline
\end{tabular}

Source: Data processing results on SPSS software

\subsection{Test a Scale of Factors by Analyzing Cronbach's Alpha Coefficients}

The results of testing the scale of the factors by Cronbach's Alpha coefficients showed that all factors have Cronbach's Alpha coefficients are $>0.7$ and observed variables in each factor have correlation coefficients with total variables $>0.5$. Thus, the observed variables in the factors can be used and they represent the properties of those factors.

Table 4. Test scale

\begin{tabular}{|c|c|c|c|}
\hline Code & The observed variables & $\begin{array}{l}\text { Total } \\
\text { variables }\end{array}$ & $\begin{array}{l}\text { Cronbach's } \\
\text { Alpha }\end{array}$ \\
\hline \multicolumn{4}{|c|}{$\begin{array}{l}\text { iversity. } \\
853\end{array}$} \\
\hline TT1 & $\begin{array}{l}\text { Lecturers always get the information about } \\
\text { HR in the university. }\end{array}$ & 0,747 & 0,790 \\
\hline TT2 & $\begin{array}{l}\text { Lecturers always get the information about } \\
\text { developing of fields in the university. }\end{array}$ & 0,725 & 0,800 \\
\hline TT3 & $\begin{array}{l}\text { Lecturers always get the information about } \\
\text { improving science-tech. }\end{array}$ & 0,703 & 0,809 \\
\hline TT4 & $\begin{array}{l}\text { Lecturers are always answered questions } \\
\text { about issues that exist in the school }\end{array}$ & 0,607 & 0,847 \\
\hline \multicolumn{4}{|c|}{ Cromoach s AMpHa $=0.142$} \\
\hline BTSDNL1 & $\begin{array}{l}\text { Arrangement and utilization the right } \\
\text { expertise and capacity of lecturers }\end{array}$ & 0,585 & 0,654 \\
\hline BTSDNL2 & $\begin{array}{l}\text { The right arrangement creates conditions for } \\
\text { lecturers to ask each other to improve their } \\
\text { capacity. }\end{array}$ & 0,691 & 0,707 \\
\hline BTSDNL3 & $\begin{array}{l}\text { Effective assignment ensures teachers' } \\
\text { professional development. }\end{array}$ & 0,553 & 0,673 \\
\hline BTSDNL4 & $\begin{array}{l}\text { Encourage lecturers to research in new, } \\
\text { specialized fields. }\end{array}$ & 0,513 & 0,696 \\
\hline \multicolumn{4}{|c|}{ MTLV. Working environment } \\
\hline
\end{tabular}




\begin{tabular}{|c|c|c|c|}
\hline \multicolumn{4}{|c|}{ Cronbach's Alpha = 0.797} \\
\hline MTLV1 & $\begin{array}{l}\text { The relationship between lecturers is } \\
\text { friendly. }\end{array}$ & 0,545 & 0,769 \\
\hline MTLV2 & $\begin{array}{l}\text { Relationship between superiors and } \\
\text { subordinates. }\end{array}$ & 0,636 & 0,740 \\
\hline MTLV3 & $\begin{array}{l}\text { Lecturers have access to a favorable } \\
\text { academic environment. }\end{array}$ & 0,507 & 0,781 \\
\hline MTLV4 & $\begin{array}{l}\text { Lecturers have conditions to refer to research } \\
\text { materials. }\end{array}$ & 0,652 & 0,734 \\
\hline MTLV5 & Lecturers believe and love teaching. & 0,554 & 0,767 \\
\hline \multicolumn{4}{|c|}{$\begin{array}{c}\text { CSDN\&TL. Remuneration and compensation policy } \\
\text { Cronbach's Alpha }=0.902\end{array}$} \\
\hline CSDN\&TL1 & $\begin{array}{l}\text { Remuneration policy commensurate with } \\
\text { work results. }\end{array}$ & 0,716 & 0,887 \\
\hline CSDN\&TL2 & $\begin{array}{l}\text { Salary and incentive policies encourage to } \\
\text { develop teaching. }\end{array}$ & 0,721 & 0,887 \\
\hline CSDN\&TL3 & $\begin{array}{l}\text { Remuneration policy ensures all parts } \\
\text { fairness. }\end{array}$ & 0,756 & 0,881 \\
\hline \multicolumn{4}{|c|}{$\begin{array}{c}\text { CSPTNNL. } \quad \begin{array}{c}\text { Policy for developing human resources of lecturers } \\
\text { Cronbach's Alpha }=0.790\end{array} \\
\end{array}$} \\
\hline CSPTNNL1 & $\begin{array}{l}\text { The university has a detail plan to develop } \\
\text { human resources of faculty. }\end{array}$ & 0,545 & 0,769 \\
\hline CSPTNNL2 & $\begin{array}{l}\text { Training and management of human resource } \\
\text { department of the university always goes } \\
\text { with the plan. }\end{array}$ & 0,636 & 0,740 \\
\hline CSPTNNL3 & $\begin{array}{l}\text { The university always aims to increase the } \\
\text { percentage of highly qualified faculty. }\end{array}$ & 0,507 & 0,781 \\
\hline CSPTNNL4 & $\begin{array}{l}\text { The university rules and regulations always } \\
\text { afford favorable conditions for the next } \\
\text { research lecturers. }\end{array}$ & 0,652 & 0,734 \\
\hline CSPTNNL5 & $\begin{array}{l}\text { The university's policy of developing human } \\
\text { resources is increasingly fair. }\end{array}$ & & \\
\hline \multicolumn{4}{|l|}{ TD. } \\
\hline TD1 & Hiring standards are higher. & 0,597 & 0,844 \\
\hline TD2 & The university attracts quality lecturers. & 0,672 & 0,834 \\
\hline
\end{tabular}




\begin{tabular}{|c|c|c|c|}
\hline TD3 & Recruitment criteria are clear and specific. & 0,621 & 0,841 \\
\hline TD4 & $\begin{array}{l}\text { The recruitment process is scientific and } \\
\text { objective. }\end{array}$ & 0,636 & 0,839 \\
\hline \multicolumn{4}{|c|}{ ĐT\&PT. } \\
\hline ĐT\&PT1 & The university supports training costs. & 0,665 & 0,864 \\
\hline ĐТ\&PТ2 & The university supports research funding. & 0,714 & 0,853 \\
\hline ĐT\&PT3 & $\begin{array}{l}\text { The university organizes training courses for } \\
\text { lecturers. }\end{array}$ & 0,632 & 0,871 \\
\hline ĐT\&PT4 & Organize scientific conferences. & 0,822 & 0,829 \\
\hline ĐT\&PT5 & $\begin{array}{l}\text { Exchange lecturers with domestic and } \\
\text { foreign university. }\end{array}$ & & \\
\hline \multicolumn{4}{|c|}{ Cobrol budrat } \\
\hline NS1 & $\begin{array}{l}\text { The university increasingly attaches } \\
\text { importance to the budget for the development } \\
\text { of human resources of faculty. }\end{array}$ & 0,585 & 0,654 \\
\hline NS2 & $\begin{array}{l}\text { School budgets are devoted to develop } \\
\text { scientific and technical research. }\end{array}$ & 0,591 & 0,707 \\
\hline NS3 & University development budget & 0,553 & 0,673 \\
\hline NS4 & $\begin{array}{l}\text { The school budget ensures the life of the } \\
\text { faculty. }\end{array}$ & & \\
\hline \multicolumn{4}{|c|}{ Y. } \\
\hline PTNNL1 & Education level of higher educated lecturers. & 0,544 & 0,656 \\
\hline PTNNL2 & $\begin{array}{l}\text { The teaching ability of the lecturers has been } \\
\text { improved. }\end{array}$ & 0,577 & 0,694 \\
\hline PTNNL3 & The lecturers's research ability is better. & 0,586 & 0,688 \\
\hline PTNNL4 & $\begin{array}{l}\text { Lecturers are more and more attached to their } \\
\text { careers. }\end{array}$ & 0,578 & 0,637 \\
\hline PTNNL5 & Lecturers are more responsible for teaching. & 0,665 & 0,864 \\
\hline PTNNL6 & The number of lecturers increased. & 0,714 & 0,853 \\
\hline
\end{tabular}

Source: Data processing results on SPSS software 
4.3 Regression Equation of the Model

4.3.1 Results of the Model's Regression

Table 5. Regression results

\begin{tabular}{|c|c|c|c|c|c|c|c|c|}
\hline \multirow{2}{*}{\multicolumn{2}{|c|}{ Model }} & \multicolumn{2}{|c|}{$\begin{array}{l}\text { Unstandardized } \\
\text { Coefficients }\end{array}$} & \multirow{2}{*}{ 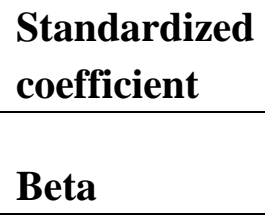 } & \multirow[b]{2}{*}{$\mathbf{T}$} & \multirow[b]{2}{*}{ Sig. } & \multicolumn{2}{|c|}{$\begin{array}{l}\text { Collinearity } \\
\text { Statistics }\end{array}$} \\
\hline & & B & Std. Error & & & & Tolerance & VIF \\
\hline \multirow[t]{9}{*}{1} & (Constant) & 0,888 & 0,033 & & 0,027 & 0,003 & & \\
\hline & TT & 0,88 & 0,009 & 0,077 & 9,275 & 0,000 & 0,763 & 1,311 \\
\hline & BTSD & 0,561 & 0,023 & 0,223 & 9,301 & 0,000 & 0,581 & 1,722 \\
\hline & MTLV & 0,112 & 0,073 & 0,15 & 7,67 & 0,000 & 0,649 & 1,542 \\
\hline & CSDN\&TL & 0,14 & 0,008 & 0,386 & 14,842 & 0,000 & 0,609 & 1,641 \\
\hline & CSPTNNL & 0,048 & 0,009 & 0,013 & 15,165 & 0,000 & 0,426 & 2,352 \\
\hline & TD & 0,224 & 0,037 & 0,55 & 13,03 & 0,000 & 0,556 & 1,799 \\
\hline & ĐT\&PT & 0,164 & 0,012 & 0,402 & 4,211 & 0,000 & 0,654 & 1,528 \\
\hline & $\mathrm{NS}$ & 0,077 & 0,013 & 0,215 & 17,396 & 0,000 & 0,670 & 1,493 \\
\hline
\end{tabular}

Dependent variable: Y: Human resource development of non-public university faculty.

Source: Results processed on SPSS from author's survey data

The results of the Enter method shown in the table that show the accepted model with 8 factors affecting the development of non-public university faculty. The regression equation is written as follows:

$$
\begin{aligned}
& \text { PTNNL }=0,888+0,08 * \text { TT }+0,561 * \text { BTSD }+0,112 * \text { MTLV }+0,14 * \text { CSĐN\&TL + } \\
& 0,048 * \text { CSPTNNL }+0,224 * \text { TD }+0,164 * \text { ĐT\&PT }+0,077 * \text { NS }
\end{aligned}
$$

\begin{tabular}{|c|c|c|c|c|c|c|c|c|c|}
\hline \multirow[t]{2}{*}{ Model } & \multirow[t]{2}{*}{$\mathbf{R}$} & \multirow[t]{2}{*}{$\mathbf{R}^{2}$} & \multirow{2}{*}{$\begin{array}{c}\text { Adjusted } \\
\qquad \mathbf{R}^{2}\end{array}$} & \multirow{2}{*}{$\begin{array}{c}\text { Standarded } \\
\text { Error of the } \\
\text { Estimate }\end{array}$} & & & & \multicolumn{2}{|c|}{ DurbinWatson } \\
\hline & & & & & $\mathbf{F}$ & df1 & df 2 & Sig. F & \\
\hline 1 & 0,842 & 0,71 & 0,700 & 0,548 & 70,616 & 6 & 250 & 0,00 & 2,085 \\
\hline
\end{tabular}

Table 6. Summary regression model

a. Prediction: (Constant): TT, BTSD, MTLV, CSDN \& TL, CSPTNNL, TD, DT \& PT, NS.

b. Dependent variable PTNNL. 


\subsubsection{Perform Tests of a Regression Function}

Tests performed include:

- Test the multi-collinearity phenomenon of the model.

The results in Table 5 show that the VIF of the independent variables are all less than 10, so we can conclude that the model does not have multicollinearity

- Test the correlation and autocorrelation phenomenon of the independent variables.

The results showed that the coefficient Durbin - Watson $\tilde{n}=2.085$. (see Table 6) it can be concluded that the model has no correlation and autocorrelation because according to Trong Hoang and Chu Nguyen Mong Ngoc (2005) in the case when $n>200$ does not have a lookup table, it can be applied experimental inspection rules:

When the Durbin - Watson coefficient $0<=\tilde{\mathrm{n}}<1$, there is a positive correlation.

When $\tilde{\mathrm{n}}: 1=<\tilde{\mathrm{n}}<=3$, there is no correlation.

When $\tilde{\mathrm{n}}: 3=<\tilde{\mathrm{n}}<=4$, there is an inverse correlation.

- Verify the model's constant variance.

In this study, the author uses the Spearman rank correlation test between normalized residuals and independent variables. If the Spearman correlation sig value between the normalized residue (ABSRES) and the independent variables is $>0.05$, it can be concluded that no variance change occurs.

The test results show that all Spearman correlations between the normalized residuals (ABSRES) and the independent variables are $>0.05$. See appendix.

- Verifying the suitability of the model with the data set.

The results of ANOVA analysis table show that sig of the model $=0.00$, so the used model is completely consistent with the whole.

ANOVA Analysis Table

\begin{tabular}{|l|l|l|l|l|l|l|}
\hline Model & & Sum of Squres & Df & Mean Square & F & Sig. \\
\hline 1 & Regression & 190,902 & 10 & 21,211 & 70,616 & 0,00 \\
\hline & Residual & 78,098 & 250 & 0,300 & & \\
\hline & Total & 269 & 256 & & & \\
\hline
\end{tabular}

Source: Data processing results on SPSS software

- Test the standardized residue of the model

Performing this test, the author uses P-P Plot diagram, the results show that the dots are concentrated in the form of a diagonal, thus assuming the normal distribution of the residual 
is not violated. See appendix.

So, after performing the tests of linear regression, the test results are satisfactory, the model can be used. The model of the impact of managing activities on the development of non-public university faculty is shown:

Formal research model used:

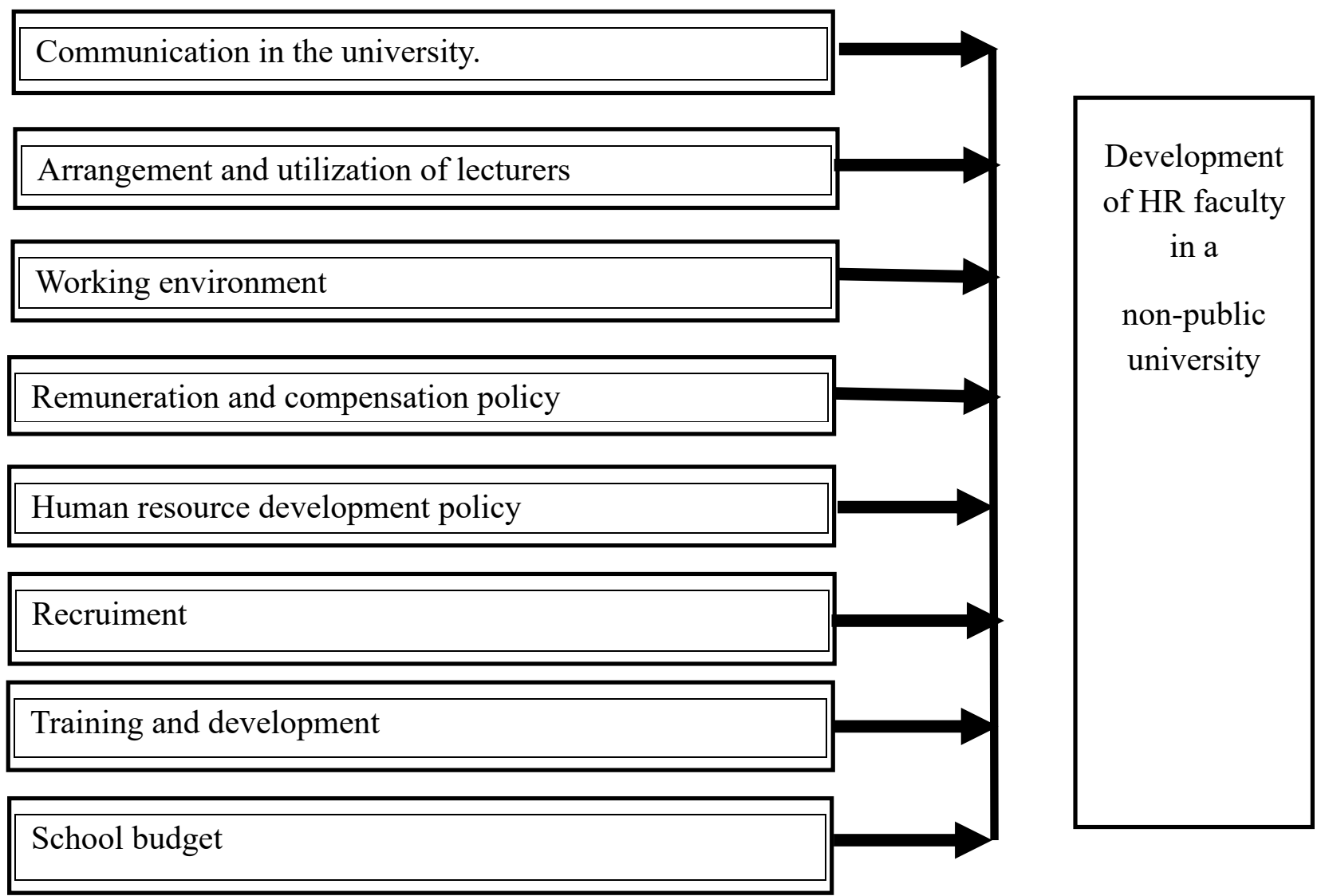

Source: Suggetion from the author

\section{Conclusion and Implications}

\subsection{Conclusion}

From the regression results in table 5 shows that there are 8 important factors affecting the development of human resources faculty in the non-publich university through such factors as: TT, TD, BTSD, MTLV, CSD \& TL, CSDPT, NS. The level of impact of these 8 factors can be explained by $71 \%(\mathrm{R} 2=0.71)$ of the change of the agricultural development (Development of human resources of non-public university faculty).

All 8 factors have regression coefficients $(+)$ (see table 5). This proves that all 8 factors have positive effects in the same direction with the dependent variable of Medicine (PTNNL), that means they have a positive impact on the development of faculty human resources of the university. 
Based on the Beta coefficient (standardized regression coefficient), see Table 5, we know the strong influence of the factors on the variable agricultural development (Development of human resources of non-public university faculty), respectively. : TD $>$ ĐT\&PT $>$ CSĐN\&TL $>$ BTSD $>$ NS $>$ MTLV $>$ TT $>$ CSPTNNL. The variable of TD has the strongest and CSPTNNL has the weakest impact.

Given the importance of these variables, managers should focus on variables ranked highly influenced because each change of them will lead to a large variation of the variable $\mathrm{Y}$ (PTNNL). In non-public universities, to develop faculty of lecturers, managers should first focus on recruitment (TD). This is completely consistent with the current situation of Vietnam, because most of the non-public universities want to have good lecturers, the most important issue is still the initial human resource collecting. This is decisive to the development of the university's lecturers in the future.

\subsection{Administrative Implications}

Regression results of the model of factors affecting the development of human resources of non-public university faculty have suggested some of the following issues for managers:

Firstly, the development of faculty human resources of non-public universities is mainly based on the internal strengths of each university. This is different from public universities, the development of human resources of faculty mainly depends on the Own Department of the Government (the Ministry of Education and Training), and Government support (from policy, investment, finance, etc.).

Secondly, due to recruitment factor (TD) has the strongest influence on the development of human resources of faculty, non-public universities need to focus on doing well this work. To do this, university should step by step innovate and improve the criteria for recruiting staff to the university, ensuring the recruitment of qualified staff, capable of developing university lecturers. Need to complete the recruitment process, recruitment policy.

Thirdly, complete the training and development of the university's faculty because it is the most important factor deciding the development of faculty human resources in terms of quality, so non-public universities need to implement. Well, some of the following measures to improve the positivity and minimize the negative effects of this factor on the development of university faculty human resources. In order to do that, non-public universities need to renew training programs and training methods for young lecturers, and need to perfect policies on professional training for young lecturers.

Fourthly, improve the working environment for the faculty. There is also a factor that have an effect on the faculty development. Improved working environment includes: improving the relationship between superiors and subordinates; the relationship between lecturers; build a good academic environment to facilitate the ability of lecturers to develop their expertise;

Finally, the policy of remuneration and compensation for lecturers. This factor is also very important to attract high quality human resources from outside to university and keep talented 
lecturers in the school. To improve this factor there are a number of issues to note:

- Improve the material and spiritual life of the lecturers

- Evaluation criteria for lecturers' performance should be specific, clear and transparent.

- Salary policy should be associated with the achievements of the lecturers.

In addtional, it is necessary to have solutions to increase operating budget in non-public universities. The research results show that this factor also has a significant impact on the development of human resources of non-public university faculty. To increase the budget for the school there are some basic solutions such as:

- Developing scientific research services for production facilities to increase revenues for the university.

- Improving the quality of training to serve as a basis for tuition fees from learners.

- Expand types of training services to increase income for the university.

- Use financial resources effectively, cut unnecessary investments.

\section{References}

Akiba, M., Chiu, Y. L., Shimizu, K., \& Liang, G. (2012). Teacher salary and national achievement: A cross-national analysis of 30 countries. International Journal of Educational Research, 53, 171-181. https://doi.org/10.1016/j.ijer.2012.03.007

Briggs, S. (2005). Changing roles and competencies of academics'. Active Learning in Higher Education, 6(3), 256-268. https://doi.org/10.1177/1469787405057753

Bunyi, G. W., Wangia, J., Magoma, C. M., \& Limboro, C. M. (2013). Teacher preparation and continuing professional development in Kenya: learning to teach early reading and mathematics. Unpublished manuscript, Kenyatta University, Nairobi. Retrieved from http://etdlibrary. ku. ac. ke/bitstream/handle/123456789/6593/Teacher\% 20Preparation\% 20 and $\%$ 20Continuing. pdf

Ellis, V., McNicholl, J., \& Pendry, A. (2012). Institutional conceptualisations of teacher education as academic work in England. Teaching and Teacher Education, 28, 685-693. https://doi.org/10.1016/j.tate.2012.02.004

Feather, D. (2010). A whisper of academic identity: an HE in FE perspective. Research in Post-Compulsory Education, 15(2), 189-204. https://doi.org/10.1080/13596741003790740

Goswami, D. (2010). Teacher training programme of Academic Staff College, Gauhati University: An appraisal. University News 48, 10, 22-28.

Grange, A., Herne, S., Casey, A., \& Wordsworth, L. (2005). Building research capacity. Nursing Management, 12(7), 32-37. https://doi.org/10.7748/nm2005.11.12.7.32.c2040 
Griffin, G. A. (Ed.). (1983). Staff development.Eighty-second year book of the National Society for the Study of Education. Chicago: University of Chicago Press.

Griffin,G. A. (Ed.) (1983). Staff development. Eighty-second year book of the National Society for the Study of Education. Chicago: University of Chicago Press.

Hales, A., \& Clarke, A. (2016). So you want to be a teacher educator? The job advertisement as a construction of teacher education in Canada'. Asia-Pacific Journal of Teacher Education, 44(4), 320-332. https://doi.org/10.1080/1359866X.2016.1193842

Hales, A., \& Clarke, A. (2016). So you want to be a teacher educator? The job advertisement as a construction of teacher education in Canada. Asia-Pacific Journal of Teacher Education, 44(4), 320-332. https://doi.org/10.1080/1359866X.2016.1193842

Khan, I. A. (2012). Relevance of Teacher Development: The EFLContext of Saudi Arabia, Procedia social and behavioral sciences. Sciencedirect, 756-764. https://doi.org/10.1016/j.sbspro.2012.06.730

Kljakovic, M. (2009). Developing a teaching research culture for general practice registrars in Australia: a literature review. Asia Pacific Family Medicine, 8(6), 1-7. https://doi.org/10.1186/1447-056X-8-6

Koster, B., Brekelmans, M., Korthagen, F., \& Wubbels, T. (2005). Quality requirements for teacher educators. Teaching and Teacher Education, 21(2), 157-176. https://doi.org/10.1016/j.tate.2004.12.004

Kwakman, K. (2003). Factors affecting teachers' participation in professional learning

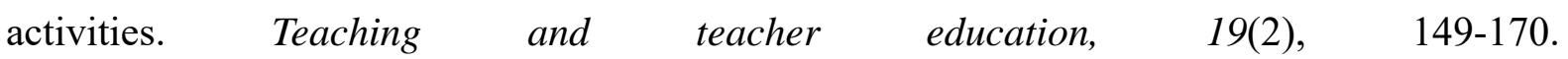
https://doi.org/10.1016/S0742-051X(02)00101-4

Kwame, A., Kattie, L., John, P., \& Jo, W. (2013). Improving teaching and learning of basic maths and reading in Africa: Does teacher preparation count? International Journal of Educational Development, 33(3), 272-282. https://doi.org/10.1016/j.ijedudev.2012.09.006

Lee, I. (2008). Understanding teachers' written feedback practices in Hong Kong secondary classrooms. Journal of Second Language Writing, 17, 69-85. https://doi.org/10.1016/j.jslw.2007.10.001

Levine, R., Russ-Eft, D., Burling, A., Stephens, J., \& Downey, J. (2013). Evaluating health services research capacity building programs: implications for health services and human resource development. Evaluation and Program Planning, 37(1), 1-11. https://doi.org/10.1016/j.evalprogplan.2012.12.002

Mikkelsen, A., \& Grønhaug, K. (1999). Measuring Organizational Learning Climate. A Cross-National Replication and Instrument Validation Study Among Public Sector Employees. Review of public personnel administration, 19(4), 31-44. https://doi.org/10.1177/0734371X9901900404 


\section{Macrothink}

Ministerie van OC\&W, \& HBO-raad. (2004). Vernieuwd convenant lectoren en Kenniskringen in het hoger beroepsonderwijs. Den Haag: Ministerie van OC\&W, and HBO-raad.

Pawar, I. A., \& Mouli, S. C. (2008). Impact of training on university and college teachers: an empirical study. University News 46, 49, 14-20.

Pratt, M., Margaritis, D., \& Coy, D. (1999). Developing a research culture in a university faculty. Journal of Higher Education Policy and Management, 21(1), 43-55. https://doi.org/10.1080/1360080990210104

Tigelaar, D. E. H., Dolmans, D. H. J. M., Wolfhagen, I. H. A. P., \& Van der Vleuten, C. P. M. (2004). The development and validation of a framework for teaching competencies in higher education. Higher Education,

https://doi.org/10.1023/B:HIGH.0000034318.74275.e4

\section{Copyright}

Copyright for this article is retained by the author(s), with first publication rights granted to the journal.

This is an open-access article distributed under the terms and conditions of the Creative Commons Attribution license (http://creativecommons.org/licenses/by/4.0/). 